\section{Toplam Kalite Yönetimi anlayışı çerçevesinde Ataşehir Toplu Konut yerleşmesinin değerlendirilmesi}

Prof. Dr. Nesrin Dengiz - Yrd. Doç. Dr. Deniz. Onat Incedayı MSÜ Mimarlık Fakültesi, Mimarlık Bölümü

* Bu makale, Mimar Sinan Üniversitesi Araştırma Fonunca desteklenen "Toplu Konutlarda Kalite Sorunu ve Çözüm Yollarının Araştırılması" konulu Araştırma Projesinin bir bölümünün değerlendirmesidir. Makalenin, Giriş ve Sonuç Bölümleri "Toplu Konutlarda Toplam Kalite Yönetimi Anlayışı" başlığıyla, "Önce kalite" Dergisinin 38. sayısında yayınlanan bildiriden geliştirilerek güncellenmiștir.

\section{Giriș}

Genelde "nitelik " sözcüğüule eş anlamda kullanılan "kalite" kavramı, "Toplam Kalite Yönetimi" anlayışı çerçevesinde, konu alanıyla ilgili hizmet verilecek kesimin gereksinmelerinin, istenilen düzeyde karşılanma yeterliliğini ifade etmede kullanılmaktadır.

ANSI / ASQC Standart A3 (1978) ve ISO 08402: 1987 standartlarında "kalite", "ürün ya da hizmetin belirlenen ya da ima edilen ihtiyaçları karşılama yeteneğine dayanan özelliklerin ve karakteristiklerin bütünüdür" (Altaş 1994, 38).

Benzer ifadeler, TSE'nin tanımında da yer almaktadır. Buna göre kalite, "bir ürün veya hizmetin belirlenen veya olabilecek gereksinmeleri karşılama yeteneği, yeterliliği ya da performansına( ${ }^{(1)}$ dayanan özelliklerinin toplamıdır."(2) Burada "gereksinme " ve "performans" birbirleriyle ilişkili iki önemli öge olarak ön plana çıkmaktadır.

Bir ürünün veya hizmetin belirlenmiş gereksinmeleri karşılamadaki performansı, o ürün ya da hizmetin "nitel", başka bir deyişle, "kalite" düzeyini belirlemektedir. "Tanınmamış gereksinmelerin karşılanması", "verimlilik", "amaca uygunluk", kullanıcı memnuniyeti" günümüzün kalite anlayışının ana kavramlarıdır (Dengiz, 1998, 87).

ISO 9000 serisi(3) kalite standartlarıyla, tüm üretim ve hizmet sektörlerinde benimsenip uygulanan ve yapım alanında da yankı bulan, "Toplam Kalite Yönetimi" anlayışında ise "kalite", merkezinde insan gereksinmelerinin karşılanması amacı bulunan ve yönetilebilen bir süreç içinde üretilen bir olgu olarak ele alınmaktadır. Edward Deming ve Joseph Juran'ın yaklaşımındaki temel unsurlar; "sürekli gelişme", "işin standardizasyonu", "esneklik" ve "takım çalışması"dır. (Koç 1998, 141). Koşulları bir sistem bütünlüğünde tarif edilmemiş, denetimsiz bir "üretim" ya da "hizmetin" söz konusu olduğu durumlarda, "kalite"yi yakalamak olanaksız olmaktadır. Söz konusu yaklaşımda ürünün değil, ürünü üreten sürecin incelenmesi ve denetlenmesi öngörülmektedir. geliştirdiği "Toplam Kalite"
Nitelik konusu, günümüzün toplu konut uygulamalarının en çok tartışılan başlıklarından birini oluşturmaktadır. Ataşehir Toplu Konut Yerleşmesinin nitel değerlendirmesi son günlerde, değișik ke-

simlerce sıklıkla sözü edilen "Toplam Kalite Yönetimi" anlayıșı çerçevesinde yapılmaktadır.

Günümüzün kalite anlayıșı ve Toplam Kalite yaklaşımında, toplu konut üretim sürecinin ağırlık noktasında yer alan kullanıcı, tasarımcı ve uygulayıcı kesimin, istek ve görüşleri doğrultusunda büyük önemi bulunmaktadır. Bu bağlamda, her üç kesime uygulanmıs bulunan anket bulgularının değerlendirilmesi sonucunda, Ataşehir Toplu Konut Yerleşmesi'nin nitelik düzeyinin belirlenmesi amaçlanmaktadır.

summary:

Today one of the most discussed issues about housing estates is 'quality'. Here the 'quality' of a housing estate, Atasehir is evaluated. According to the ideas brought by Total Quality Management today new

approaches of 'quality'and 'Total Quality' emphasize the importance of the 'user',

designer' and 'constructor', which are the main tree groups of a quality production process. In this paper, we have tried to determine the level of "quality" of Ataşehir Housing Development. Anahtar Kelimeler: Toplu Konut, Kalite, Toplam Kalite Yönetimi ISO 9000 Serisi Kalite Standartları Kullanıc1-Tasarımcı-Uygulamacı Kesim Keywords: Housing Estate, Quality Total Quality Management ISO 9000 Quality Standarts User-Designer-Constructor Groups 
I Performans. "Kalitenin en önemli boyutudur. Ürünün kendinden beklenen işlevi ne derecede yerine getirdiğini gösteren bir ölçüdür".

(Özveren 1997, 43)

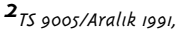

"Kalite Sözlü̆̆̈̈"

3 IsO 9000 serisi, "imalat

ve hizmet endüstrilerinde

kalite güvencesi için

kurulmuş kapsamlı bir

standart kümesidir.

Bir işletmenin kalite

sistemini gelistirmesini.

belgelenmesini ve

çalıştırmasını ister."

(özveren 1994, 121.)

4 Prof. Dr. Ibrahim

Kaurakoğlu, kalite

kauraminin

a) tasarım kalitesi,

b) uygunluk kalitesi

olmak üzere iki bileşenden

oluştuğunu ifade

etmektedir.

(Kaurakoğlu 1998, 11-12).

$5_{\text {Ataşehir Yerleşmesi, }}$

'kullanicı Memnuniyeti

Anket Çalışmaları', 100 adet

kullanic ile yapilmıştir.

$\sigma_{\text {Ataşehir yerleşmesinin }}$

mimari projelerindirme

çalışmalarına büyük oranda

katılmıs olan mimar ile

bir çeure tasarımcısının

değerlendirmelerinden

yararlanılmıştır. Daha

sinırlı sayıda mimarî

tasarım çalıșmaları yapmı

olan diğer iki mimardan

yanıt alınmamiştır.

7 Ataşehir 2. ve 3.

Etaplarında çalışan $\sigma$ adet

uygulamacı firma

sorunlarını ile önceden

düzenlenen sorunların

kapsaminda görüşmeler

yapilmıştır.
"Kaliteli bina ya da fizikî çevre" ifadesi ile kullanıcının gereksinimlerini en uygun biçimde karşılayan, bu özelliğini zaman içinde koruyan, estetik ve ekolojik açılardan çevre kirliliği yaratmayan, toplum yararını gözetecek, uygun fiyatta ve uygun sürede gerçekleştirilmiş olan bir yapım ürünü ya da çevre oluşumu tanımlamaktadır.

Kaliteli ve sağlıklı bir yaşam çevresinin oluşturulması için tasarım uygulama süreçlerinin bu yeni kalite anlayışı çerçevesinde yürütülmesinin yanısıra yaşam kültürünün örgütlenmesi, siyasî alışkanlıkların değiştirilmesi gibi, çok geniş bir alanda, birçok yenilikçi adımların atılması da gerekli olmaktadır. Kalitenin, yaşamın tüm alanlarını kapsayan ekonomik ve toplumsal politikalar olmaksızın, yanlızca fiziksel mekân üretimine yönelik, yasal düzenlemeler, standartlar ve organizasyonlardan beklenemeyeceği de açıktır.

"Tasarım" ve "uygulama" çalışmalarının performansına bağlı olamayacağı da ortadadır. Yaşanabilir bir çevrede, belirlenen gereksinmelere uygun kalite düzeyinin ancak plancı, tasarımcı, uygulamacı, kullanıcı vb. gibi, bu süreçte yeralan, tüm birey ya da kuruluşların katılım ve katkılarının söz konusu olduğu bir üretim modeli çerçevesinde gerçekleşebilmesi olasıdır.

Kisaca, toplu konut yerleşmelerinde istenilen kalite düzeyinin oluşturulması için, mevcut siyasî, ekonomik ve toplumsal politikalar doğrultusunda nitel özellikleri belirlenen işin, planlama, ihale edilme ve bunlarla ilgili yasa, yönetmelik ve standartların hazırlanması aşamalarından, tasarım, uygulama, kullanım aşamalarına kadar uzanan üretim sürecinin, bir sistem yaklaşımı çerçevesinde ele alınarak yönetilmesi gerekli olmaktadır. Bu yaklaşımda, kalite oluşum sürecinin ağırlık noktası, "kullanıc1", "tasarımc1" ve "uygulayıcı" kesimin birbirleriyle olan iletişim ve ilişkilerinde düğümlenmektedir. Kalite düzeyi ise, büyük ölçüde, "tasarım" kalitesi ile "uygulama" (uygunluk) kalitesine bağlı olarak oluşmaktadır (4). İster tasarım, ister uygulama (yapım) aşamalarında olsun, yapma çevrenin performansının değerlendirilmesinde, kullanıcıların, teknik, fiziksel, psikolojik, sosyolojik, ekonomik vb. gereksinmelerine ne düzeyde cevap arandığ (Dengiz ve Onat 1999, 387-388). Burada, performans kavramının, tarihsel süreç içindeki gelişimiyle ilgili olan bir özelliğine dikkat çekmek yararlı olacaktır. Performans kavramının, yapım alanında uygulandığı ilk dönemlerde, daha çok teknik ve fiziksel gereksinmelere ağırlık verilirken, bugün gelinen nokta, kalitenin değerleri ile birlikte psikolojik ve sosyo- kültürel gereksinmelere de bağlı olarak ifade edilebilmesidir (Altaș 1994, 38).

Ataşehir yerleşmesinin nitelik düzeyinin irdelendiği bu çalışmada yöntem olarak, yerinde gözlem, görüşme, inceleme ve anketlerden yararlanılmıştır. Tartışma ve değerlendirme bulgularının oluşturulması amacıyla kullanıcı, tasarımcı ve uygulayıcı kesimin, her birine yönelik anketler düzenlenmiş ve sorular yöneltilmiştir. Kullanıcı anket sorularının(5) hazırlanmasında fiziksel, görsel (estetik) ve sosyal etkileşim parametreleri olmak üzere, 3 temel parametre göz önünde bulundurulmuştur (Dülgeroğlu vd. 1996, 9).

Yerleşmenin iç ve dış mekânlarının tasarımını yapan mimarî bürolara yöneltilmiş soruların düzenlenmesinde, tasarım sürecinde dikkate alınan öncelikler ile karşılaşılan sorunlar ağırlık kazanmıştır (6). Uygulamacı firmalara yöneltilen (7) sorularda ise odak noktası, tasarım ürününün 
nitelikli biçimde uygulanmasında izlenen, yeni iş yönetimi biçimleri, "Toplam Kalite Yönetimi" anlayışı çerçevesinde geliştirilen " kalite güvence sistemleri" ile "işçilik" sorunları üzerine yoğunlaşmıştır.

II. Anket Bulgularının Değerlendirilmesi

\section{A. Kullanıcı Memnuniyeti Anketi}

\section{Değerlendirmesi}

Ataşehir'de yerleşenlerin \% 77'lik çoğunluğunu, daha önce İstanbul içinde yaşamakta olan aileler, \%23'lük bölümünü ise, İstanbul dışından gelenler meydana getirmektedir.

Kullanıcıların \%79'luk kısmını yüksek eğitim almış kişiler, önemli bir bölümünü de ilgililerden edinilen bilgilere göre, çalışanlar oluşturmaktadır. Orta-üst ve üst gelir gruplarına ait aileler $\% 90$ 'lık bir yüzde ile çoğunluktadır.

Kullanıcıların \% 58'i mülk sahibi iken, $\% 42$ 'si kiracı konumundadır. Yukarıda, kısaca özetlenen sosyo-kültürel ve ekonomik özelliklere sahip kullanıcı grubuna yöneltilen anket ve yerinde yapılan gözlem sonuçlarının, iç ve dış mekânlarla ilgili değerlendirmesi aşağıdaki şekilde özetlenmektedir:

\section{Fiziksel Parametrelere Göre Yapılan Değerlendirmeler:}

Mekânların fiziksel parametreleri olarak ele alınan;

-İklim (sıcaklık, nem, hava hareketi vb.) -Işık (aydınlatma düzeyi, frekans vb.) ve -Boyutlar (genişlik, uzunluk, yükseklik) ile ilgili özellikler, kullanıcı üzerinde çeşitli duygusal ve algısal değişimlere neden olmalarından dolayı, tasarım çalışmalarının önemli ve etkili bir boyutunu oluşturmaktadır. Ayrıca, fiziksel parametreler kapsamında, konutların iç ve dış mekânlarının işlevsellik ve güvenlik konusundaki özellikleri ile kullanıcı tarafından algılanış biçimleri de, tasarımcı açısından büyük önem taşımaktadır.

Ataşehir'de yapılan anket çalışmalarının sonuçlarında, kullanıcıların \%89'luk bölümü, fiziksel konfor ve çevre koşullarından memnun olduklarının belirtmektedir (Şekil 1). Öncelikle, konutlara ait planimetrik kararlar, kullanıcılar tarafından beğenilmektedir. Planlamanın yanısıra, mekân çözümleri ve organizasyonları, çoğunlukla "iyi" olarak nitelendirilmektedir.
Şekil: I Konutun genel değerlendirmesi 
Şekil: 2

Konuttan beklenen

yaşam tarzının bulunup

bulunmadığinın

değerlendirilmesi

şekil: 3

Konuttun iş̧ilik

açısından değerlendirilmesi
Konutların sunduğu yaşam tarzının, sürdürmek istedikleri yaşam tarzı olduğunu \%86'lık bir kesim ifade etmektedir (Şekil 2). Mekân boyutlarıyla ilgili olarak, genelde memnuniyet duyguları dile getirilirken, mutfak boyutları ve depolama olanaklarının yetersizliğinden şikayetçi olanlar \%37'lık bir grubu oluşturmaktadır. Kullanılan malzeme ve mobilya ile ilgili olarak, kullanıcıların yarıdan fazlası beğenisini belirtmektedir. Duvar ve döşeme kaplamaları ile ilgili olarak \%31'lik kesim "vasat", \%28'lik kesim ise "kötü" yanıtını vermektedir.
İşcilik konusunda memnuniyetsizliğini belirtenler \% 70'lere ulaşmaktadır (Şekil: 3 ). İşçilik kalitesi konusunda, özellikle "kalite güvence sistemi" ne sahip olmayan uygulayıcı firmalar tarafından yapılmış olan konutlarda, cevaplar çoğunlukla, "vasat" ve "kötü" olarak işaretlenmiştir. "iyi" yanıtı, ancak \%28'lik kesimden alınmıştır. Bu nedenle konutların kullanım sürecinde masraf çıkartmalarıyla ilgili soruya \%60’lık kesim "evet" cevabını vermektedir. Rahatsızlık yaratan konulardan bir diğeri de yalıtım sorunları ile ilgilidir. Toplu konut bloklarının yapımında 
uygulanan tünel kalıp sisteminin, olumsuz yanlarından biri olarak kabul edilen ses yalıtımı konusunda, önlemler alınmış olunmasına rağmen, ciddi memnuniyetsizlik ifadeleriyle karşılaşılmaktadır. Bu konu ile ilgili yanttlardan, ancak \%46'llk kesiminin memnuniyet belirttiği görülmektedir (Şekil 4). Büyük bir çoğunluk, rüzgar ve asansörün titreşim sesinden rahatsız olduklarını belirtmektedir. Özellikle antre, koridor ve sslak hacimlerde hissedilen ses geçirgenliğinden, önemli sayılacak oranlarda şikayetler gözlenmektedir. Güvenlik konusunda da, bazı sorunların yaşandı ğına dair bulgular dikkat çekmektedir. \%37'lik kesim, yangına karşı konutlarını yeterince güvenli bulmamaktadır. Deprem konusunda ise, $\% 40$ oranında güvensizlik ortaya çıkmaktadır.

Konutların işlevsel özelliklerinin değerlendirilmesinde ise en önemli ölçüt, kullanım esnekliği konusunda, kullanıcıya sağlanan olanaklardır.

"Tasarım esnekliği" açısından yapılan değerlendirmelerde, tünel kalıp teknolojisi uygulamasının doğal bir sonucu olarak, konut iç mekânlarında, önemli sayılabilir hiçbir değişikliğe olanak tanımayan ve şekil: 4

Mekânların ses gürültü özelliğinden memnuniyet şekil: 5 Yaşantıdaki değiş̧iklikler nedeniyle konutta değişiklik yapma gerekliliği 
Resim: I

Konut blokları önündeki dış mekan düzenlemelerinden esnek olmayan bir yapıyla karşılaşılmaktadır. Bu konu, Ataşehir konutlarının mekân kurgusuyla ilgili en olumsuz yönlerinden birini oluşturmaktadır. Bilindiği üzere, zaman içindeki işlevsel eskimeye bağlı olarak, konutun hızlı biçimde değer yitirmesini önlemenin yolu, "esnek" tasarımlarla mümkün olabilmektedir. Mutfak, banyo, W.C. gibi sabit servis mekânları dışında mekânların, ailenin ekonomik, demogafik, sosyo-kültürel yapısındaki gelişmeleri paralelinde, bazı değişikliklerin yapılabilmesine olanak sağlayacak esneklikte tasarlanmış, kullanıcıların hazır yaşam kalıplarına değil, içerisinde yaşamaktan zevk alacakları, kendi yaşam biçimlerine uygun mekânsal düzenlemeler yapabilecekleri şekilde tasarlanmaları beklenmektedir. Kullanıcının tasarım sürecine bu anlamda katılması, kendisi için yaratılmış olan bu esneklik ortamı, fizyolojik olduğu kadar psikolojik olarak da bir değer ve konfor özelliği taşımaktadır. Ataşehir konutlarının, işlevsel esneklik olanakları bakımından incelenmesine de, \%38'lik bir kesim konutlarının yeni olmalarına karşın, iç mekânlarında değişiklik yapma gereksinimi duyduklarını belirtmiştir (Şekil 5). Bu durumda, zaman içinde olabilecek değişimler karşısında ise, bina içinde mekânsal düzenlemede değişiklik yapma esnekliği bulunmadığından tek çözümün, ev değiş̧irme (mobilite) olacağı gözükmektedir.

\section{Görsel (Estetik) Parametrelere Göre Yapılan Değerlendirmeler:}

$\mathrm{Bu}$ çevrede tasarımın, nitelik düzeyini yükseltici etkileri olan, "görsel çeşitlilik", "işlevsel çeşitlilik", "mekânsal çeşitlilik" gibi öğelerin, ne ölçüde ve ne biçimde kullanıldıkları değerlendirilmektedir.

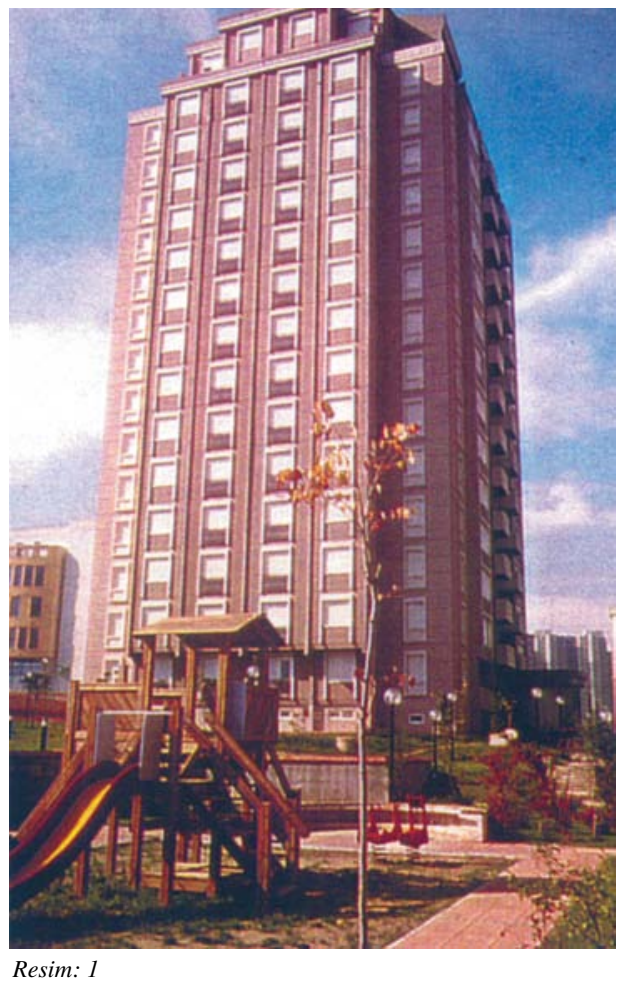

Ataşehir yerleşmesinde, mimarî ve fiziksel çevrenin, tünel kalıp teknolojisinin beraberinde getirdiği kısıtlamaların baskısı altında, biçimlenmiş olduğu görülmektedir.

Ancak içinde bulunan koşullar çerçevesinde, Ataşehir'de mimarî kalite düzeyinin yükseltilmesinde, tam olarak başarıya ulaşıldığını söylemek kolay görünmemektedir.

Binaların mimarî niteliğinde genelde görülen vasatllğın yanında, dış mekânların düzenlenmesinde, farklı ve olumlu çabaların harcandığı gözlemlenmektedir (Resim 1). Bu sonuçlardan kullanıcıların önemli bir yüzdesi memnun olduklarını, hatta \%86'lık bir kesim Ataşehir'i tercih nedenlerinin başında, çevre donanımı ve düzenleme biçiminin tatmin edici düzeyde olmasının geldiğini belirtmektir (șekil:6).

Bloklar arasında yaratılan mekânsal sürpizler ve açılımların, uygun boyutlarda 


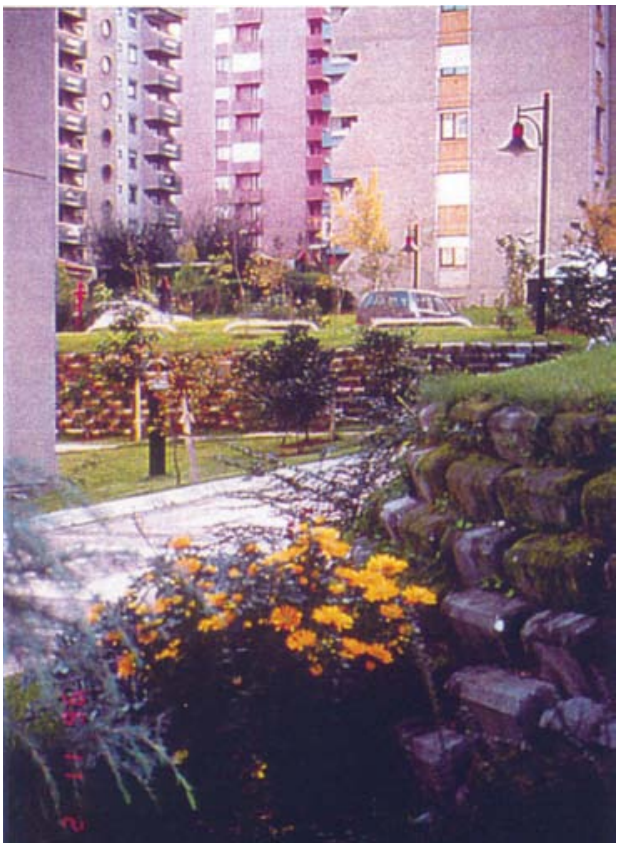

Resim: 2

tasarlanmış olması, kullanıcı üzerinde, ferahlık, rahatlık gibi duygular uyandırarak olumlu karşılanmaktadır. Ayrıca, bu alanların çeşitli nitelikte peyzaj ögeleri ve sanatsal çalışmaları ile donatılması beğeni görmektedir (Resim 2). Kent yaşamını imgeleyen cadde, sokak, avlu, meydan gibi sosyo-kültürel öğelerin ise kişilerde güçlü mekân etkisi ve görsel tatmin duygusu sağladı ̆̆ gözlenmektedir. "Konut imaji" açısından, çok katlı yüksek konut tiplerinin, toplu konut uygulamalarında, niteliksel değerlere çözüm getirmede çok uygun olmadıkları sonucu ortaya çıkmaktadır. Kullanıcı özleminin ve tercihinin, \%89'lara varan oranlarda, iki katlı, bahçeli konut tipinden yana olduğu saptanmaktadır (Şekil 7). Ancak ilgililerden edinilen bilgilere göre, prestij ve sosyal statü sembolü olarak ya da özgürlük ve şekil: 6 Ceure açısından konutun değerlendirilmesi Resim: 2 Ortak alanlara ait peyzaj düzenlemeleri şekil: 7 Kullanıcının ideal konut tipi 


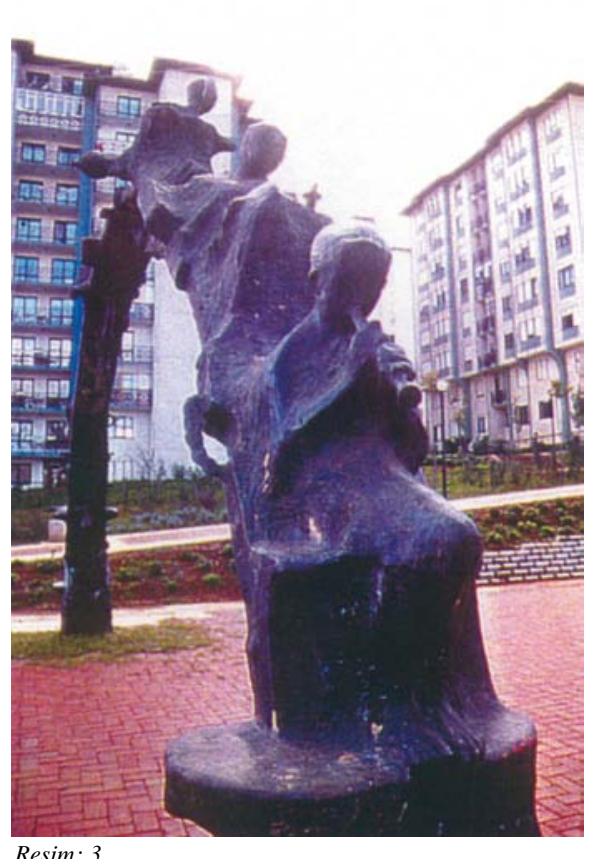

Resim: 3

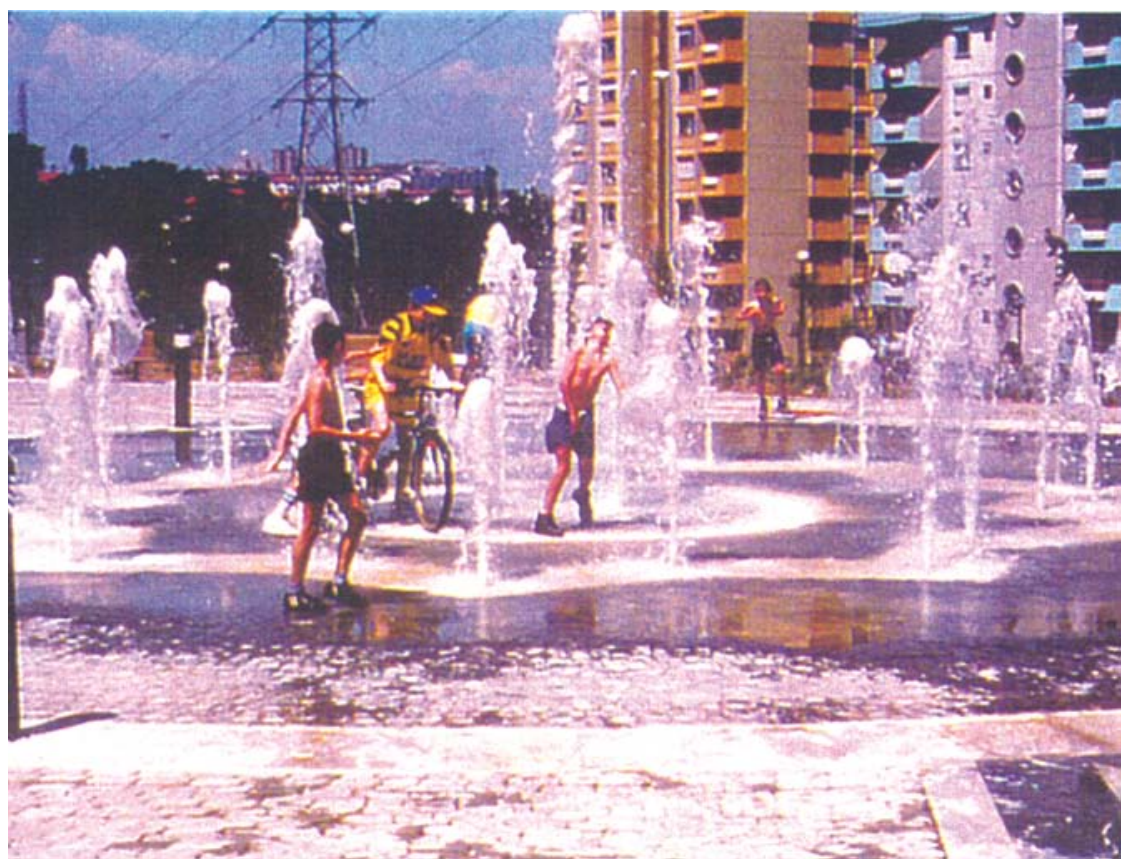

Resim: 4 sükuneti çağrıştırdığı için, yüksek konut bloklarının ve stüdyo tiplerinin özellikle genç ve çalışan kesim tarafından tercih edildiği de görülmektedir.

\section{Sosyal Etkileşim Parametrelerine göre Yapulan Dĕgerlendirmeler:}

Konut tasarımında, aile bireyleri arasındaki iletişim kopukluklarını ve kuşaklararası çatışmaları azaltmak, hatta önlemek için kişilerin, diğer aile üyelerinin görsel denetimden uzak kalabilecekleri, arkadaşlarını ağırlayabilecekleri, varsa hobilerini gerçekleştirebilecekleri, sahiplenebilecekleri sınırları belirli bir oda, bir alan ya da köşenin varlığı önemli olmaktadır. İnsanlara, istediklerinde yalnız kalabilme, istediklerinde diğer insanlarla sosyal ilişki kurabilme imkânı veren tasarımlar, kullanıcılar tarafından tercih edilmektedir. Bu bağlamda ilgililer, Ataşehir'de 4 odalı konutlara olan talebin, 3 odalı tiplere göre daha yüksek olduğunu belirtmektedir. İnsanların sosyal etkileşim gereksinimlerini karşılamada, bina çevresinin mekânsal ve donanım kalitesi de önemli olmaktadır. Ataşehir bu bakımdan yeterli nitelik ve çeşitlilik düzeyine sahip görünmektedir (Resim 3-4). Ortak sosyal alanları kullanma, toplanma, yürüme, açık alanlarda oturma, spor yapma, oyun oynama vb. gibi, günlük yaşam içinde yapılan ve insanlar arasındaki sosyal etkileşimi güçlendiren eylemlerin gerçekleştirilme olanağı, burada yapılmış olan çevre düzenleme çalışmalarıyla büyük ölçüde yaratılmıştır. Kullanıcıların \%80'i yaşadıkları çevre düzenini, sosyal ilişkileri geliştirici ve yaşam kültürlerine uygun olarak değerlendirilmektedir. Ancak sosyal etkileşimi sağlayan temel unsurlardan biri olan komşuluk ilişkilerinin, fizikî çevrede yaratılan bu olanaklara rağmen oldukça zayıf olduğu, kullanıcıların büyük bir bölümü tarafından dile getirilmektedir. Bu konuda, tasarım sürecinde, komşuluk ilişkilerine olumlu katkıda bulunmak amacıyla alınmış kararlarının yeterli düzeyde görülmemelerine karşın, açık yaşama alanlarının taşıdığ 1 nicel ve nitel özelliklerin, çoğunluk için olması 
gereken ölçüler içinde olduğu izlenimi vermektedir.

Anket sonuçlarına göre çevre düzenlemesi, yeşil alan kullanımı ve yeterliliği açısından saptanan memnuniyet yüzdesi $\% 91$ 'lik bir oranla, oldukça yüksek düzeylerdedir.

Blokların çevre düzenlemeleri ile ilgili çözümler ise \%71 oranında beğenilmektedir.

\section{B- Tasarımcı Anketi Sonuçlarının Değerlendirilmesi:}

Tasarımcı, öncelikle; arsa edinme, ihale ve uygulama aşamalarının işleyişinde, bazı aksaklıkların ve yanlışlıkların bulunduğunu belirtmektedir. Arsa edinme politikalarındaki yanlışlıklar, arsa bedellerinin değerlerinin üzerine çıkmasına ve öngörülen hedeflerden sapmalara neden olduğundan, sözkonusu uygulamanın konut açı̆̆ını kapatmaktan çok, yatırım amaçlı kullanıma hizmet ettiğine dikkat çekilmektedir. Aynı şekilde, makro planlama ölçeğinde toplu konut alanlarının belirlenmesinde, bilinçli bir yaklaşımın varlığından söz etmenin oldukça güç olduğu belirtilmektedir. Belediye İmar Yönetmenliği'ne bağlı kısıtlamalar çerçevesinde geliştirilen mevzi imar planları ile elde edilen düzenlemelerin de, bir çok yanlışlığı beraberinde getirdiği vurgulanmaktadır. Mevzi imar planlarının, mimarî tasarım sürecinin bir parçası olarak görülmesi gerektiği ve ancak böylelikle, daha sağlıklı ve nitelikli sonuçların alınabileceği ifade edilmektedir.

İhale sistemindeki aksaklıklar, planlı ve organize olamama, yüklenici firmalar ile girişimci arasında yapılan sözleşmeler, tasarımcı için birçok açıdan (süre, nitelik vb.) kısıtlayıcı ve zorlayıcı olmaktadır. İşin süresini tanımlayan zaman diliminde, tünel kalıp sistemi uygulamalarının, kaçınılmaz bir zorunluluk sonucu ortaya çıktığı belirtilerek, en etkili tasarım boyutu olarak, yapım teknolojisi gösterilmektedir. Tasarımcılar, yasal ve sözleşmelere bağlı kısıtlamaların (ihale koşulları, şartnameler, standartlar vb.) olumlu ve olumsuz taraflarından da söz etmektedirler. Olumlu yön olarak, tüm tasarımcı ve yüklenicilerin uymak zorunda kaldıkları iç ve dış mekân standartlarının varlığı gösterilmekte; olumsuz yön olarak ise, çok sınırlı sayıdaki nitel özelikleri içeren standartlara bağlı kalınmış olmanın, kalite düzeyini arttırıcı araçlardan biri olarak kabul edilen, farklı nitelikte ve çeşitlilikteki malzemelerin kullanımını engellediği şeklindeki görüş ile dile getirilmektedir. Tasarımcılar, sosyal ilişkilerin güçlendirilmesi amacıyla, değişik büyüklüklerde konut tiplerinin birarada çözülmesi yoluna gidildiğini, ailelerin görsel mahremiyetlerinin sağlanması için ise bloklararası mesafelere dikkat edildiğini, bitişik balkon yapılmaktan kaçınıldığını ve daireler arasında oldukça güçlü yalıtım teknikleri uygulandığını bildirmektedirler( ${ }^{(8)}$.

Konut bloklarının, güvenlik sistemi açısından yeterince tatminkar oldukları, girişlerde sekürite cam sistemleri, dumandan korunma odaları, bağımsız elektrik sistemleri vb. gibi güvenlik çözümlerinin kullanıldığı, tünel kalıp teknolojisinden kaynaklanan ses yalıtımı sorununun, döşemelerde kum dolgular yoluyla giderilmeye çalışıldığı, tesisat dolapları ve bacalarıyla kolay bakım yolunun sağlandığı, çöp bacalarında file malzemesi kullanılarak baca bitiş detayları geliştirildiği belirtilmektedir.

Tünel kalıp uygulamalarda, "esneklik" konusunda karşılaşılan yetersizliklerin, tasarım çalışmalarının önemli bir sorununu oluşturduğu ve çözüm yolu olarak,

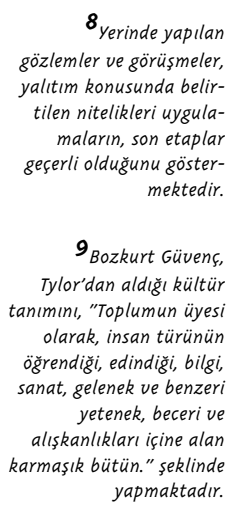

10 Sayı 3, Mayıs 2003 
kullanıcıya çok çeşitli tiplerde konut seçenekleri sunma yoluna gidildiği, anket çalışmaları ve "örnek daire" uygulamaları yoluyla da kullanıcı görüş ve eleştirileri alınarak, bir anlamda "kullanıcı katılımı"nın da sağlandığg ifade edilmektedir.

Çevre düzenlemeleri konusunda, toplu konut alanlarının nitelik düzeyinin yükseltilmesine yönelik yapılan çalışmalarda, öncelikle boyut olarak, mekânların "amaçlarına uygun olarak düzenlenmesi" ilkesinin benimsendiği belirtilirken, sözleşmelere bağlı kısıtlamalar nedeniyle, sosyal etkileşim ve komşuluk ilişkileri konusunda, tasarım çalışmalarının yetersizliğinden de söz edilmektedir. Bu bağlamda, konut tiplerinin daha fazla çeşitlendirilebilmesi ve yükssek blokların yanısıra az katlı, bahçe ile ilişkili konut çözümlerine de yer verilmesiyle, daha başarılı sonuçlara gidilebileceği vurgulanmaktadır. Buna karşılık, çevre ile ilgili yapılan tasarımlarda, fırsat eşitliği yaklaşımıyla sosyal donanımlardan eşit şekilde yararlanabilme ilkesinin göz ardı edilmediği, yapılan çevre tasarımı çalışmalarında, yerleşmenin kendine özgü kimlik özelliklerine sahip olması yönünde çabalar sarf edildiği dile getirilmektedir. Çevrenin, kullanıcının kültürel değerleri ile uyumlu olmasının önemine de dikkat çekilmektedir. "Kültür"ün tanımında da ifade edildiği gibi ${ }^{(9)}$ bir bütün olarak, tüm işlevsel özellikleriyle, toplu yaşamın organize edildiği toplu konut yerleşmelerinin tasarımında, sosyokültürel veriler, tasarımcı için büyük bir önem taşımaktadır.

Tüm tasarımcılar, biçimsel ve estetik değerlerin önemini yadsımamakla birlikte, sosyo-kültürel değerlerle ilişkili yaşam çevresi kimliği ve çağdaş görünüm özelliklerini, öncelikli aranan değerler olarak ele almaktadır. Nitelikli ve sağlıklı yaşam çevrelerinin oluşumunda tasarımcıların, üzerinde önemle durdukları diğer bir konu da, katı ihale şartlarının iyileşmesi ve mimarların tasarım özgürlüklerinin bu denli sınırlandırılmaması doğrultusundaki görüşleriyle ilgili olmaktadir.

Devlet İhale Kanunu ile İmar Yasası ve yönetmeliklerinin, yeni bir bakış açısıyla ele alınmalarının ve getirilen sınırlamaların, disipline edici ve denetleyici rollerinin yanında, sanatçının yaratıcı özgürlüğünü yok etmeyecek biçimde düzenlenmelerinin gerekliliği üzerine dikkat çekilmektedir.

\section{C-Uygulayıcı Anketi Sonuçlarının Değerlendirilmesi:}

Tasarım çalışmaları tamamlanan binaların yapım aşamasında, uygulama ve işçilikle ilgili performans düzeyini ölçmek ve uygulanan iş yönetimi sistemlerini değerlendirmek amacıyla, uygulayıcı firmalara yöneltilmiş soruların değerlendirme sonuçları ise, şu şekilde özetlenebilmektedir:

Ataşehir yerleşmesinde uygulamayı yürüten yüklenici firmaların, genelde işi belli bir kalite anlayışı, proje yönetimi ve iş akışı denetimi çerçevesinde sürdürdükleri anlaşılmaktadır. Buna rağmen, işçilik sorunları ve şikayetleri gündeme geliyorsa bunun daha çok netleşmiş kalite ve iş yönetimi anlayışları bulunmayan firmalardan kaynaklandığı görülmektedir. Kullanıcı beğenisinin de, kalite yönetimi sistemleri bulunan firmalarca üretilen konutlardan yana olması, bu sonucu doğrulamaktadır. Yüklenici firmalardan bir adedi, ISO 9001 Kalite Güvence Sistemine sahiptir. Bir diğeri ise, başvuruda bulunarak, sistemin koşul ve gerekle-rine uygun, iş üretimi ortamının hazırlık çalışmalarını sürdürmektedir. 
Tüm yükleniciler, TSE standartlarına uygun koşullarda çalışmakta ve TSE markalı araç ve malzeme kullanmaktadır. Ancak, TSE standartları esas alınarak uygulanan denetim sistemi genelde yeterli bulunmamaktadır. Emlak Bankası uygulama sorumlusuna yöneltilen sorulara verilen yanıtların değerlendirilmesiyle, bankanın herhangi bir "kalite politikasının" olmamasının, çalışanların bu konuyla ilgili yeterince bilgilendirilmemesinin, organizasyonel yapı, yetki ve sorumlulukları tanımlayan bir dokümanın bulunmamasının, uygulamada çeşitli aksaklık ve olumsuzlukların doğmasina neden olduğu sonucu ortaya çıkmaktadır.

Kalite güvence sistemine sahip bulunmayan yüklenici firmalar genelde, kendi koşullarına uygun bir kalite yönetim politikaları bulunduğunu belirtmektedir. Kalite güvence sisteminin getirilmesiyle, gerçekleşen ya da beklenen olumlu gelişmeler, firma yetkililerince aşağıdaki şekilde sıralanmaktadır:

1- Hatalı uygulamalar sonucu oluşan maliyetler azalmakta, işçilik sorunları en aza indirilmektedir.

2- Kullanıcı memnuniyeti artmaktadır.

3- Yapılan işlerin nitelik düzeyi ile işgücü verimliliği yükselmektedir.

4- Malzeme alımlarındaki hataların önüne geçilmektedir.

5- Proje yönetimi ile ilgili dokümantasyonları düzene girmektedir.

6- İş kazalarında azalma olmaktadır.

Kalite güvence sistemi uygulamasının yüklenici firma yetkilileri tarafından, olumsuz olarak değerlendirilen yönleri ise şöyle sıralanmaktadır:

Sistemin ülkemiz için yeni olması ve yeterince tanınmamasının, uygulamada, özellikle standartlara uymada, yeterli has- sasiyetin gösterilmemesi sonucunu yarattığından söz edilmektedir. Bir firma ise, kırtasiyenin artışını olumsuz yön olarak göstermektedir. Tünel kalıp teknolojisi kullanımının sonuçları "ekonomi, verimlilik, hız, mimari tasarıma getirdiği kısıtlamalar, esneklik" vb. gibi açılardan değerlendirildiğinde, firmaların \%80'i genelde memnun olduklarını, \%20'lik bir kesim ise memnuniyetsizliklerini belirtmektedir.

Bununla birlikte, memnuniyetini belirten firmalar, "sistemin" mimariye getirdiği kısıtlamalardan şikayetçi olmaktadırlar. Yapım sistemi tercihinin ihale şartlarından birinci derecede etkilendiği ve genel durum değerlendirmesinin, içinde bulunulan koşullar düşünülerek yapılması gerektiği vurgulanmaktadır. Varolan ortam ve ihale şartlarında, "süre" faktörünün zorlayıcı etkisi ve tünel kalıp sisteminin bu konuda getirdiği avantajlardan dolayı, kolaylıkla tercih edilebileceğine dikkat çekilmektedir. Bir firma, daha yüksek standartta konut üretiminin söz konusu olduğu durumlarda, tünel kalıp sisteminin uygun bir tercih olmayacağı görüşünü dile getirmektedir. Vasıfsız işçilik sorununu aşmak için alınan önlemlerle ilgili olarak firmaların yarısı, kendi elemanlarını uzun yıllar çalıştırarak ve yetiştirerek, bir çözüm ürettiklerini belirtmektedir. $\mathrm{Bu}$ sorunun uzun vadeli çözümü konusunda ise, "eğitim"in tek seçenek olduğu görüşünde birleşilmektedir.

\section{Sonuç}

Toplu konutlarda istenilen kalite düzeyinin oluşturulmasında; işin planlama-örgütleme- ihale edilme konusuyla ilgili yasal düzenlemelerinin yapılması aşamalarından başlayan, tasarım, uygulama, hatta kullanım 
aşamalarına kadar uzanan ve bir "sistem" yaklaşımıyla ele alınması gereken çok boyutlu bir üretim süreci söz konusu olmaktadır.

$\mathrm{Bu}$ süreçte yeralan tüm kişi ve kuruluşların gösterdikleri performans düzeyi, yaşam çevresi kalitesinin oluşumunda önemli rol oynamaktadır (Yenersoy 1997, 58-59). İstenilen kalite düzeyinin oluşumunda, "tasarım" ve "uygulama" aşamalarının nitel düzeyleri en önemli belirleyiciler olmaktadır.

Nitelikli bir yaşam çevresi denildiğinde, günlük hayatın rahat ve konforlu biçimde sürdürülmesi amacıyla belli standartlar gözetilerek oluşturulmuş bir ortam anlaşılmamalıdır. Çünkü yaşanabilir çevre kavramı, kullanıcının kültürel ve duygusal gereksinimlerinin karşılanabildiği ölçüde, anlam, değer ve nitelik kazanmaktadır. Mimar tasarım sürecinde kullanıcı gereksinimlerine, çevresel ve ekolojik veriler, ekonomik ve teknik veriler, kültürel ve sosyal veriler, artistik ve estetik veriler gibi parametreler çerçevesinde en uygun çözümü üretebilmek için, konuyla ilgili uzmalar ekibiyle işbirliği yaparak çalışmalarını yürütmek durumundadır. "Toplam Kalite Yönetimi" anlayışının da, temel unsurlarından biri olan "ekip çalışması"nın tasarım sürecindeki önemi, günümüzde her kesim tarafından, tartışmasız kabul edilen bir olgu olmaktadır. Ancak, Ataşehir Yerleşmesi'nde, bu aşamaya ilişkin çalışmaların, yukarıda sözü edilen özelliklere tam uymadığı görülmektedir.

Teknoloji seçimi, mekânsal ve mimarî nitelik düzeyinin belirlenmesinde, en etkili boyutlardan biri olarak kabul edilmektedir. Toplu konut uygulamalarının önemli bir çoğunluğunda ve Ataşehir örneğinde de görüldüğü gibi, mimarî ürünün, ekonomik ve teknolojik rasyonelliğin baskısı altında kalarak biçimlenmiş olması, mimarî ve mekansal açıdan olumsuz sonuçların doğmasına neden olmaktadır.

Çevre nitelik düzeyinin yükseltilmesi, büyük oranda uygulama koşulları ve kullanıcı gereksinmeleriyle uyumlu olarak sürdürülen yaratıcı sentez çalışmalarının ürünü olan "tasarım"ın nitel düzeyine bağlı olmaktadır. Bu çerçevede yasal düzenlemelerin de, günün ve ortamın koşul ve gereksinmelerine uygun hale getirilmesi, nitelikli çevrenin oluşum sürecinde, bağlayıcı ön koşullar olarak ayrıca büyük önem taşımaktadır.

Toplu konut yerleşmelerinin sunduğu yaşam çevresinin, zamanla önce nitel özelliklerini kaybetmesi ya da kısa sürede yetersizleşmesini önlemenin başlıca yolları olarak "kullanıcı katılımını sağlayan modeller", "esnek tasarım çözümleri" ve "çeşitli tipte seçenek sunma" yolları sayılabilmektedir. Bireylerin yaşadıkları çevreyle uyum içinde olmaları, ona yabancılaşmamaları, onu benimsemeleri ve onda kendilerini geliştirici özellikler bulabilmeleri, " kullanıcı katılımının" sağlanabildiği oranlarda ve durumlarda gerçekleşebilmektedir. Diğer taraftan, kişilerin yaşam çevreleriyle aktif ilişkilerinin, katılım ve kullanımlarının, işlevsel olduğu kadar sosyal, kültürel ve psikolojik düzeylerde söz konusu olabildiğinde ancak nitelikli ve yaşanabilir bir çevreden söz edilebilmektedir (Robert1999, 50). Ataşehir Yerleşmesi'nde, kullanıcıya esneklik sağlayıcı yol olarak "çeşitli tipte seçenek sunma" yaklaşımı benimsenmiştir.

Yaşam çevresine yönelik kalite oluşum sürecinin ikinci önemli adımı olan "uygulama" aşamasının nitelik düzeyinin belirlenmesinde ise işin, belli örgütlenme, 
uygulama ve denetim modelleri kullanılarak, ilgili standartlar çerçevesinde yürütülmesi ve nitelikli insan gücünün varlığı önemli olmaktadır. Bu konuda, ISO 9000 serisi Kalite Güvencesi Standartları'nın yadsınamaz yol gösterici rolleri bulunmaktadır. Ataşehir'de bazı uygulayıcı firmalar, bu standartları kullanmışlardır.

Sonuç olarak günümüzde "Toplam Kalite Yönetimi" anlayışı çerçevesinde örgütlenmiş toplu konut üretim süreci ile istenilen kalite düzeyine uygun yaşam çevrelerinin oluşturulması olanaklı görünmektedir. Özellikle, toplu konut üretimi süreci ile istenilen kalite düzeyine uygun yaşam çevrelerinin oluşturulması olanaklı görünmektedir. Özellikle, toplu konut üretimi alanında etkinlik gösteren Emlak Bankası ${ }^{(10)}$ gibi kuruluşların, "Toplam Kalite Yönetimi" anlayışı çerçevesinde örgütlenerek sürdürecekleri çalışmalarıyla, daha nitelikli ve sağlıklı yaşam çevrelerine doğru, önemli adımlar atılmış olacaktır 1

\section{KAYNAKÇA:}

Altaş, N. 1994. Kalite Kavramı Üzerine Bir İnceleme: Fiziksel Çevrede Kalite Parametreleri Modeli, ITÜ Dergisi, Cilt 52, Sayı: 3-4 İstanbul.

Dengiz, N. 1998. Mimari Tasarım ve Yapım Sürecinde Standartlar ve Standartlaşma, Mimari Tasarım Sorunları Ders Notları, MSÜ Mimarlık Fakültesi Yayını, İstanbul.

Dengiz, N., Onat, D. 1999. Ataşehir Örneğinde, Toplu Konut Yerleşmelerinde Kalite Sorunu Üzerine, Ulusal Kentsel Tasarım Kongresi Kitabı, MSÜ Mimarlık Fakültesi, Sehir ve Bölge Planlama Bölümü, İstanbul.

Dülgeroğlu, Y., Aydınlı, S., Pulat, G. 1996. Toplu Konutlarda Nitelik Sorunu, T.C. Başbakanlık Toplu Konut İdaresi Başbakanlı̆̆l, Konut Arastırmaları Dizisi-4, Ankara.

Güvenç, B. 1997. Kültürün ABC'si, Yapı Kredi Yayınları, İstanbul.

Kavrakoğlu, I. 1998. Kalite, Kalite Güvencesi ve ISO 9000, Kalder Yayınları, İstanbul.

Koç, H. 1998. Kaliteli Yaşam Çevreleri Arayışında Mimarlıkta Kalite, Yapı ve Yaşam 98, Kongre Kitabı, Mimarlar Odası Bursa Şubesi, Bursa.

Özveren, M. 1997. Toplam Kalite Yönetimi, Alfa Basım, Yayım, Dağıtım, İstanbul.

Robert, J. 1999. Kent ve Halk, Kent Üzerine Alternatif Düşünceler, Ütopya Yayınevi, Ankara.

Yenersoy, G. 1997, Toplam Kalite Yönetimi, Roto Yayınları, İstanbul. TS 9005/Aralık 1991, Kalite Sözlüğ̈̈ Resmî Gazete, sayı:23466 - 17.09.1998

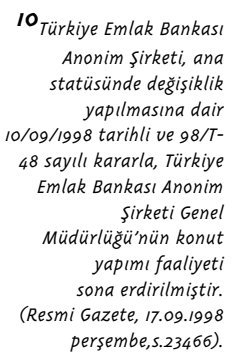

10 Türkiye Emlak Bankası Anonim Şirketi, ana statüsünde değişiklik yapilmasina dair 10/09/1998 tarihli ve 98/T48 sayılı kararla, Türkiye Emlak Bankası Anonim şirketi Genel Müdürlüğü'nün konut yapımı faaliyeti sona erdirilmiştir. (Resmi Gazete, 17.09.1998 perşembe, s.23466). 